\title{
Landslides in the Western Columbia Gorge, Skamania County, Washington
}

By Thomas C. Pierson, Russell C. Evarts, and Joseph A. Bard

Pamphlet to accompany

Scientific Investigations Map 3358

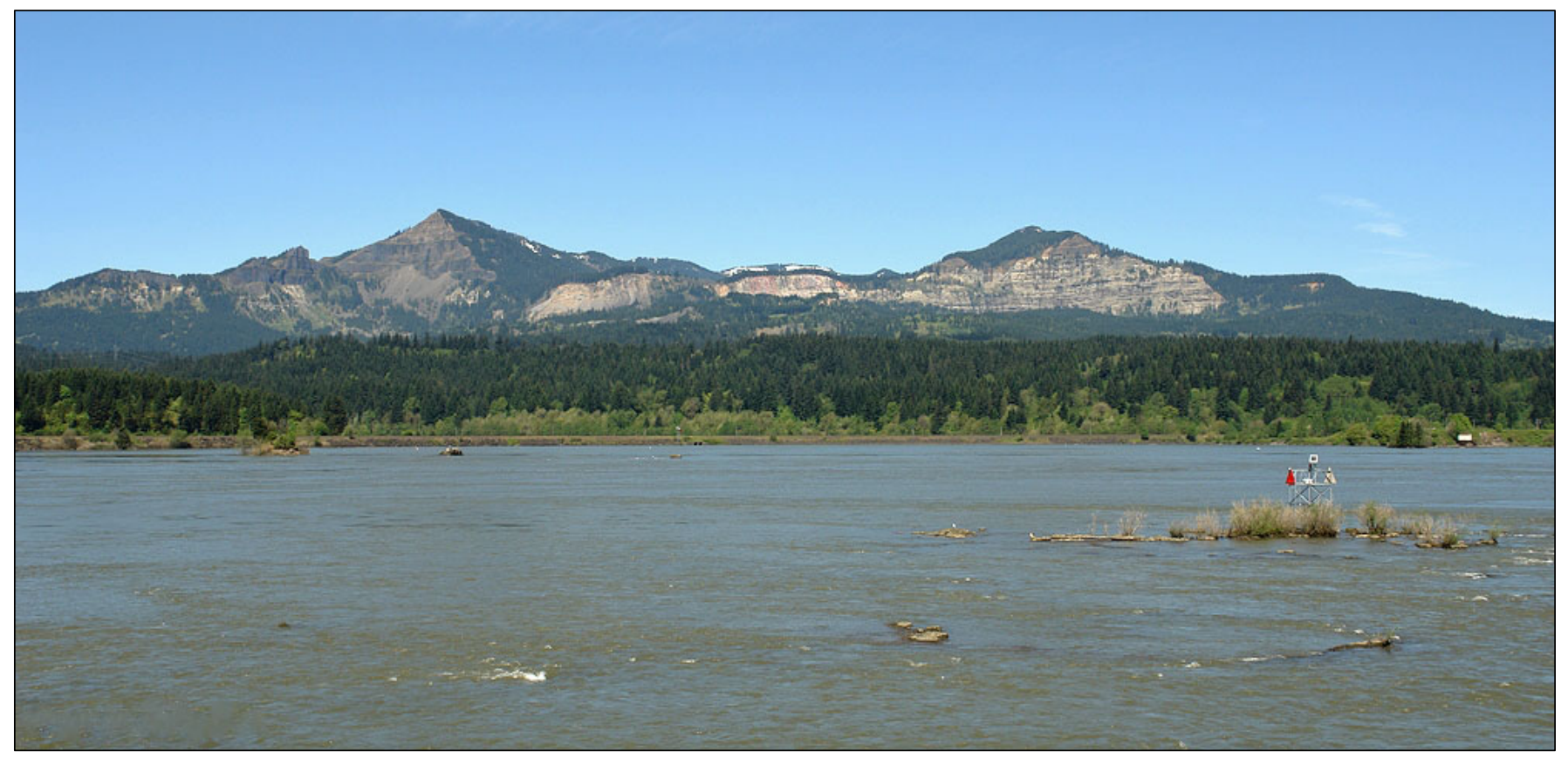

View northward from Cascade Locks, Oregon, of headscarp of the Red Bluffs landslide (most of the whitish cliff faces) and the slightly darker headscarp of the Bonneville landslide to the west (mostly below the sharp-peaked mountain on left, Table Mountain). Toe of Bonneville landslide and Columbia River in foreground. Photograph by Lyn Topinka (Copyright, 2011), published with permission. 


\title{
U.S. Department of the Interior \\ SALLY JEWELL, Secretary
}

\section{U.S. Geological Survey \\ Suzette M. Kimball, Director}

U.S. Geological Survey, Reston, Virginia: 2016

\begin{abstract}
For more information on the USGS-the Federal source for science about the Earth, its natural and living resources, natural hazards, and the environment-visit http://www.usgs.gov or call 1-888-ASK-USGS (1-888-275-8747)

For an overview of USGS information products, including maps, imagery, and publications, visit http://www.usgs.gov/pubprod
\end{abstract}

To order this and other USGS information products, visit http://store.usgs.gov

Any use of trade, firm, or product names is for descriptive purposes only and does not imply endorsement by the U.S. Government.

Although this information product, for the most part, is in the public domain, it also may contain copyrighted materials as noted in the text. Permission to reproduce copyrighted items must be secured from the copyright owner.

\section{Suggested citation:}

Pierson, T.C., Evarts, R.C., and Bard, J.A., 2016, Landslides in the western Columbia Gorge, Skamania County, Washington: U.S. Geological Survey Scientific Investigations Map 3358, scale 1:12,000, 22 p., http://dx.doi.org/10.3133/sim3358.

ISSN 2327-638X (online) 


\section{Contents}

Summary

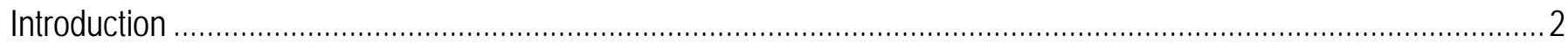

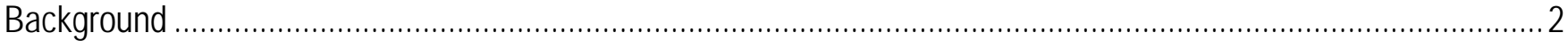

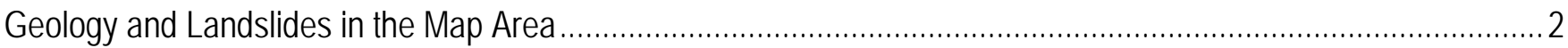

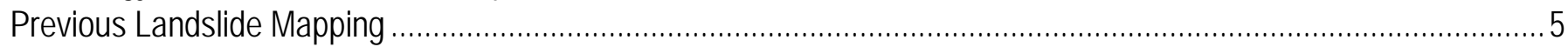

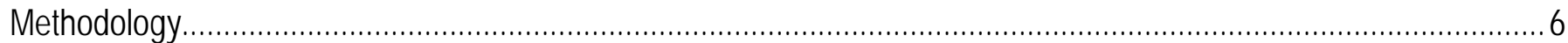

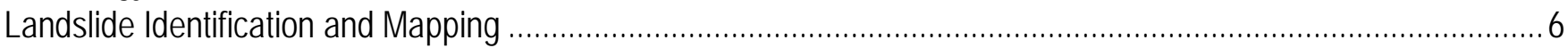

Landslide Numbering and Classification...........................................................................................

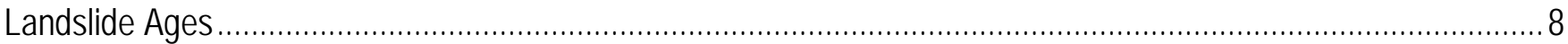

Mapping Results and Conclusions ...............................................................................................................

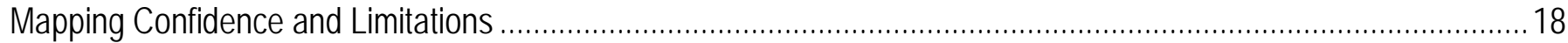

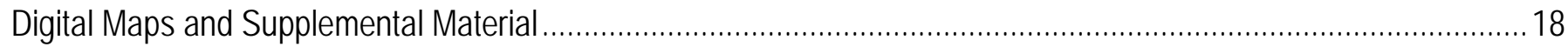

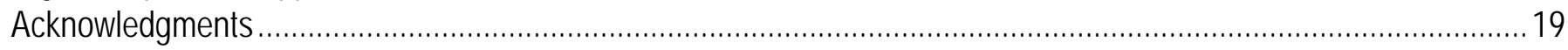

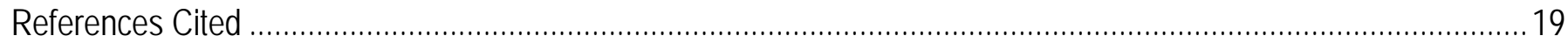

\section{Tables}

1. Types of landslide movement interpreted from topography in western Columbia Gorge, Skamania County, Washington, and movement codes used in database ................................................................... 8

2. Example row of landslide attributes shown in the landslide data table ...................................................... 8

3. Summary of total areas for different categories of landslides, western Columbia Gorge, Skamania County, Washington.

\section{Figures}

1. Simplified stratigraphic section of bedrock in the western Columbia Gorge, Skamania County, Washington ....... 3

2. Classification of landslide types based on classification of Varnes (1978) .................................................... 4

3. Previously mapped landslide complexes (brown) and known unstable terrain in the Columbia Gorge, Skamania County, Washington, including the Ruckel Landslide across the river in Oregon ....................... 6

4. An idealized rotational landslide showing commonly used terms for various features ...................................... 7

5. Simplified map of landslides in map area, showing areas of mapped slides from this study relative to areas of landslides identified in the previously mapped Skamania and Cascade landslide complexes.................. 13

6. Simplified map of landslides in map area showing estimated age ranges of mapped landslides....................... 14

7. Simplified map of landslides in map area showing landslide movement history as either first-generation landslides or reactivated landslides with one or with two or more episodes of previous movement ......... 15

8. Different views of the Piper Road landslide (also called the Rock Creek landslide), which involved parts of slides 333 and 334 and which is a reactivated part of the larger Stevenson landslide (slide 202)........... 16

\section{Appendix}

Appendix is provided online only as an Excel spreadsheet at http://dx.doi.org/10.3133/sim3358. 


\title{
Landslides in the Western Columbia Gorge, Skamania County, Washington
}

\author{
Thomas C. Pierson, Russell C. Evarts, and Joseph A. Bard
}

\section{Summary}

Recent light detection and ranging (lidar) imagery has allowed us to identify and map a large number of previously unrecognized landslides, or slides, in heavily forested terrain in the western Columbia Gorge, Skamania County, Washington, and it has revealed that the few previously recognized areas of instability are actually composites of multiple smaller landslides. The high resolution of the imagery further reveals that landslides in the map area have complex movement histories and span a wide range of relative ages. Movement histories are inferred from relative landslide locations and crosscutting relations of surface features. Estimated age ranges are based on (1) limited absolute dating; (2) relative fineness of landscape surface textures, calibrated by comparison with surfaces of currently active and dated landslides as interpreted from interferometric synthetic aperture radar (InSAR), global positioning system (GPS), and historical records; (3) sharpness and steepness of larger-scale surface morphologic features, calibrated by comparison with similar dated features in other regions; (4) degree of surface erosion; and (5) evidence of erosion or deposition by late Pleistocene (15-22 ka) Missoula floods at or below $200 \mathrm{~m}$ altitude. The relative age categories are recent ( 0 to $\sim 1,000$ years old), intermediate-age ( 1,000 to $\sim 15,000$ years old), and old ( $>\sim 15,000$ years old). Within the $221.5 \mathrm{~km}^{2}$ map area, we identified 215 discrete landslides, covering $140.9 \mathrm{~km}^{2}$ (64 percent of the map area). At least 12 of the recent landslides are currently moving or have moved within the last two decades. Mapping for this study expanded the area of previously recognized unstable terrain by 56 percent. Landslide geometries suggest that more than half (62 percent) of these slope failures are translational landslides or composite landslides with translational elements, with failure occurring along gently sloping bedding planes in zones of deeply weathered, locally clay rich volcaniclastic sedimentary units. Approximately two-thirds of the mapped landslide area comprises landslides that have remobilized parts of older slides, and 37 percent of these reactivated slides have involved reactivation of material from two or more older slides. The largest two recent landslides have volumes $\approx 1 \mathrm{~km}^{3}$ and runouts $\approx 6 \mathrm{~km}$. One of these, the Bonneville landslide, temporarily dammed the Columbia River almost 600 years ago, and subsequent dam-break flooding inundated downstream areas. The other, the Red Bluffs landslide, slid into the river adjacent to the Bonneville landslide but apparently did not form a landslide dam. Another such landslide rapidly sliding into the Columbia River today could have a catastrophic impact on downstream communities and on the transportation and energy-distribution infrastructure of the Pacific Northwest. 


\section{Introduction}

\section{Background}

Landslides are a natural hazard that affects areas of sloping terrain throughout the world. They caused several billions of dollars (USD) in damage and killed over 50,000 people from 1903 to 2004 (Nadim and others, 2006). Many parts of the Pacific Northwest, including areas of Washington and Oregon, are susceptible to landslides, owing to abundant rainfall, to ground acceleration during earthquakes, and to widespread sloping terrain that is commonly underlain by weak, unstable rock or soil resulting from combinations of tectonic deformation and uplift, rapid weathering, and deposition of loose volcanic deposits. This is especially true for the Columbia Gorge-a deep canyon cut by the Columbia River through the still-uplifting Cascade Range. On the Washington side of the western Columbia Gorge in the map area (map sheet), mean annual precipitation varies from about 2,000 mm/yr at river level to over 3,000 mm/yr at higher elevations (Washington Department of Transportation, 2013), and landslides have been common over time at a variety of scales.

Widespread distribution of at least a few large inactive and active landslides in the Columbia Gorge has been long recognized, but earlier reconnaissance mapping using aerial photography had been unable to resolve much detail because of heavy forest vegetation (Wise, 1961; Palmer, 1977; Schuster and Pringle, 2002). The recent development of land-surface imaging techniques that can penetrate vegetation cover using lidar technology is revolutionizing our ability to map and study landslides, particularly in heavily forested terrain. Digital manipulation of raw lidar point data (by using only the longest pulse returns) allows ground-surface images to be constructed that effectively remove forest vegetation and structures from the image, giving an accurate, high-resolution (6 ft/1.83 m raster resolution) representation of the bare-earth ground surface (Carrara and others, 1995). Efforts to inventory landslides using lidar in various parts of the world are revealing the existence of many more landslides than had previously been mapped (for example, Schulz, 2007; Van Den Eeckhaut and others, 2007, 2009, 2011; Burns and Madin, 2009; Haneberg and others, 2009). Lidar imagery for the Washington side of the western Columbia Gorge reveals that the amount of unstable terrain, some of it underlying towns as well as undeveloped forest land, had been similarly underestimated (Randall, 2012).

This study was undertaken to map and characterize the landslides, many not previously recognized, within an irregular swath of terrain approximately $30 \mathrm{~km}$ long and averaging about $7 \mathrm{~km}$ wide on the north shore of the western Columbia Gorge (in western Skamania County, Washington) from River Mile 134 to 153. Characterization includes estimations of relative landslide ages and the movement histories of mapped landslides in terms of previous episodes of movement. The boundaries of this study were determined in 2013 by the limits of available lidar coverage obtained in 2005.

\section{Geology and Landslides in the Map Area}

Landslides are abundant on the north side of the western Columbia Gorge. The area owes its instability to (1) abundant rainfall; (2) high relief ( $900 \mathrm{~m}$ ); (3) composition and structure of the underlying rocks; (4) post-10 Ma tectonic uplift associated with the structural evolution of the Cascade Range and Yakima Fold Belt; and (5) valley-side erosion by the incising Columbia River, which flows across the uplifting terrains (Palmer, 1977; Campbell and Bentley, 1981; Schuster and Pringle, 2002; Reiners and others, 2002; Reidel and others, 2003; Wells and McCaffrey, 2013). Erosion by the river may have been periodically but briefly accelerated by dozens of cataclysmic floods during the late Pleistocene (14.5-22 ka), which moved enormous volumes of water and sediment through the gorge at high velocities (O’Connor and Baker, 1992; O’Connor, 1993; Benito and O’Connor, 2003; Denlinger and O'Connell, 2010). All but one of these floods resulted from periodic failures of a glacier ice dam 
that impounded Pleistocene glacial Lake Missoula in western Montana. In addition to subsurface porewater pressures generated by heavy rain, local crustal and offshore subduction-zone earthquakes may periodically provide ground accelerations capable of triggering landslides in the Columbia Gorge (Keefer, 1984).

The bedrock geology of the western Columbia Gorge is dominated by Oligocene to early Miocene volcaniclastic rocks and minor interbedded lava flows of the ancestral Cascade volcanic arc (fig. 1; Waters, 1973; Palmer, 1977; Walsh and others, 1987). Mildly folded and zeolitized strata make up most of the ancestral arc section. Earlier workers (Wise, 1970; Waters, 1973; Palmer, 1977) correlated these beds with the Ohanapecosh Formation in Mount Rainier National Park (Fiske and others, 1963; Jutzeler and others, 2014), but recent unpublished work by one of the authors (R.C. Evarts) shows that the strata of the Columbia Gorge, although lithologically similar, are generally younger than and not contiguous with the Ohanapecosh Formation of the type area. In the western Columbia Gorge, the Ohanapecosh-equivalent strata were informally named the Weigle formation (Wise, 1961). Throughout much of the western Columbia Gorge, the deformed zeolitic rocks are unconformably overlain by weakly lithified, nearly unaltered volcaniclastic rocks assigned to the Miocene Eagle Creek Formation (Wise, 1961, 1970). Recent work (R.C. Evarts, unpub. mapping) shows that the Eagle Creek Formation of previous workers is divisible into two informal members: a lower member composed of dark-brown to green, epiclastic, fluvial conglomerate and sandstone and an upper member composed of light-gray, poorly sorted, sandy to bouldery volcaniclastic beds dominated by dacitic lahar deposits and derivative fluvial sediment. In many locations within the map area, the ancestral arc rocks are unconformably overlain by lava flows of the middle Miocene Columbia River Basalt Group, late Miocene to Pliocene fluvial deposits (Troutdale Formation), or Quaternary olivine-phyric mafic lavas (fig. 1; Phillips, 1986; Korosec, 1986).

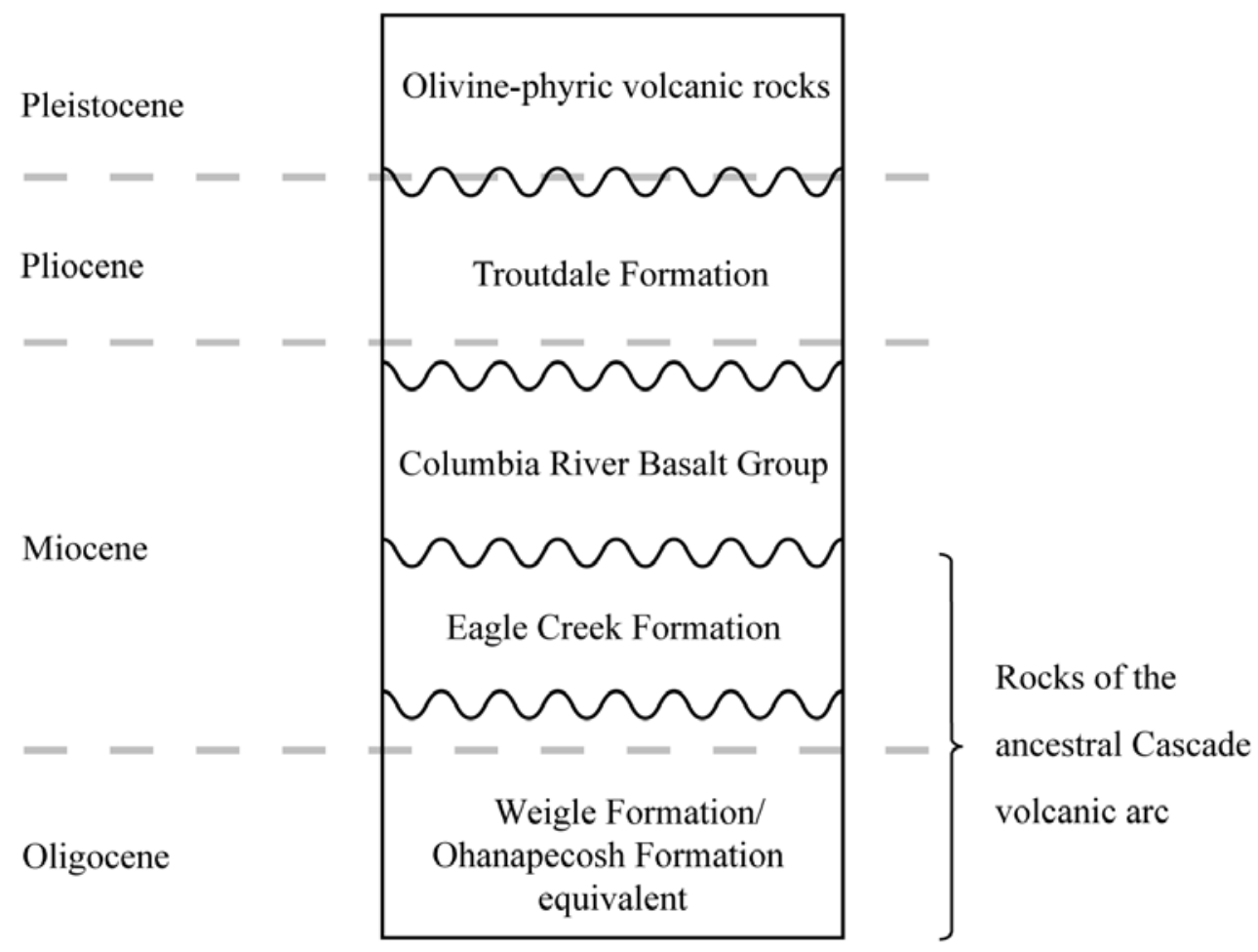

Figure 1. Simplified stratigraphic section of bedrock in the western Columbia Gorge, Skamania County, Washington. Wavy lines represent unconformable contacts between rock units. 
Considering all of the causative factors, lithology and structure are paramount and explain why the north side of the western Columbia Gorge has so many more landslides than the south side. The critical factors are (1) the presence of competent lava flows resting on weak and variably altered volcaniclastic rocks, a stratigraphic combination associated with frequent landsliding (Safran and others, 2011) and (2) the regional deformation that causes the bedded volcaniclastic sedimentary units and overlying lava flows to dip southward at $2-10^{\circ}$ toward the river. Given the deep incision by the river, some contacts and bedding planes are exposed in unbuttressed slopes on the north side of the gorge. Slickensides in borings reveal that some clay-rich weathering horizons within the Eagle Creek Formation, and probably also within the Weigle Formation, act as failure planes (Biever, 1999). These conditions have favored the extensive development of translational landslides (fig. 2) in the map area.

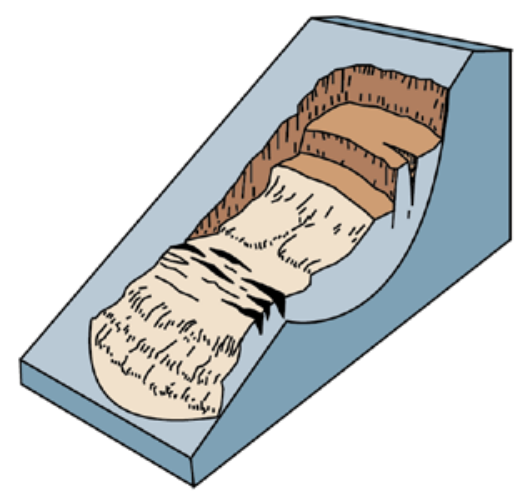

Rotational landslide

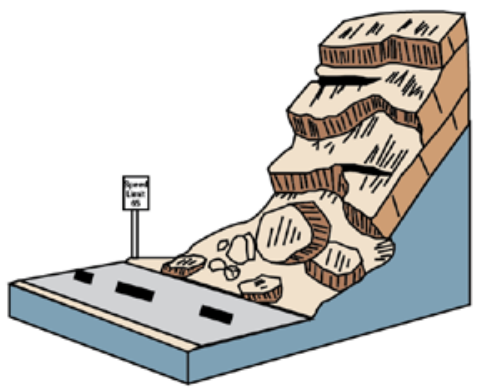

Rockfall

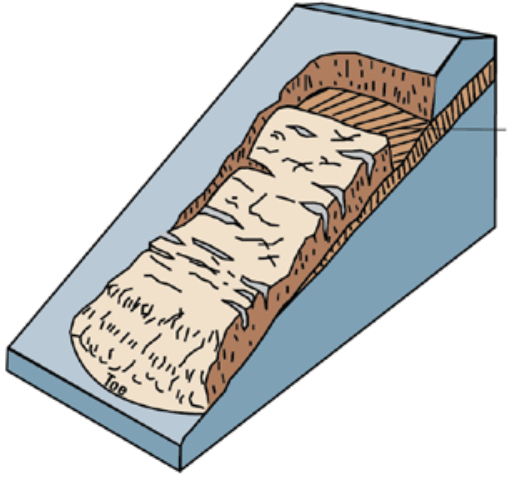

Translational landslide

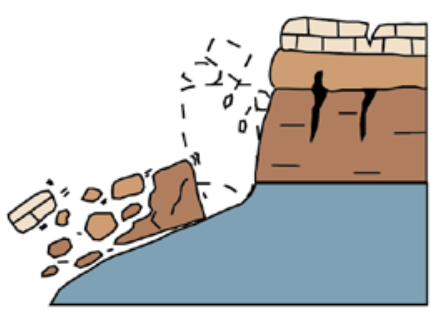

Topple

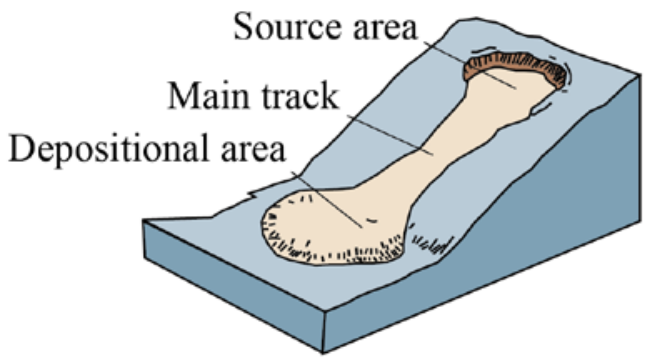

Earthflow

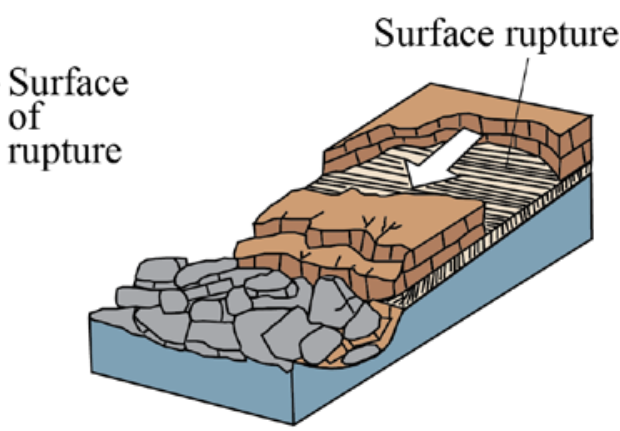

Block slide

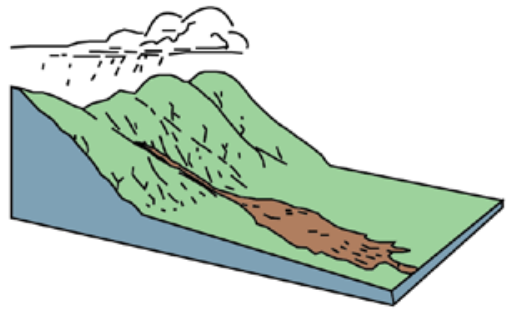

Debris flow

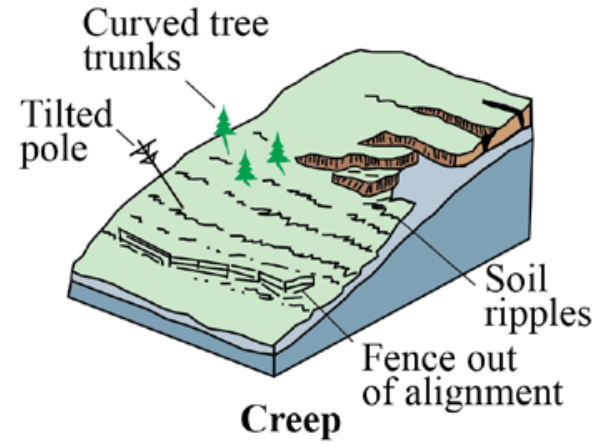

Figure 2. Classification of landslide types based on classification of Varnes (1978). Figure modified from Highland, (2004). 
However, a variety of other landslide types also have occurred here, including rock falls, rotational landslides, earthflows, and debris flows (Palmer, 1977; Schuster and Pringle, 2002; Randall, 2012). Many of the individual landslides mapped in this study appear to be combinations of two or more landslide types and are designated as composite landslides. Zones containing multiple individual landslides that overlap and intersect each other are termed landslide complexes.

Data on structure and composition of specific north-shore landslides in the western Columbia Gorge is limited. Drill logs from exploratory borings on the Bonneville landslide, obtained by the U.S. Army Corps of Engineers (USACE) in association with construction of Bonneville Dam (Holdredge, 1937; USACE, 1976 [summarized in Palmer, 1977], 1994), indicate that the Bonneville landslide (slide 301, explained in Landslide Identification and Mapping section) is a translational landslide, varying in thickness from about 30 to $150 \mathrm{~m}$, with an average thickness of about $76 \mathrm{~m}$ (mean of 14 vertical sections). It is composed of large (as much as 100-m diameter) fractured blocks of Weigle formation, Eagle Creek Formation, and younger lava flows, which are suspended in a matrix of clay-poor micaceous sand and gravel (Palmer, 1977). According to Waters (1973), the primary failure plane is located in a clay-rich saprolite horizon developed on the upper contact of the Weigle formation. However, the presence of Weigle formation rocks within the landslide mass suggests that the failure plane may be, in part, located below the saprolite. There may not be only one failure plane, however. Geotechnical borings associated with a study of the 1996 Maple Hill landslide (slide 322), a 1-km² translational slide triggered by heavy rain about $6 \mathrm{~km}$ northeast of the Bonneville slide in Stevenson (Biever, 1999), show evidence of multiple failure planes in the Eagle Creek Formation.

\section{Previous Landslide Mapping}

Landslides in the map area were first noted by the members of the Lewis and Clark expedition, who observed in 1805 that the river was obstructed by small islands and large rocks: “. . . those obstructions together with the high stones which are continually breaking loose from the mountain on the starboard side and rolling down into the chute [Cascades Rapids] . . . must be the cause of the river's damming up to such a distance above, where it shows such evident marks of the common current of the river being much lower than at the present day.” (Brandt, 2002, p. 296). Prior to that, Native Americans in the region marked the occurrence of the landslide, giving its deposit mythical meaning in legend as the "Bridge of the Gods," because the river-damming slide debris allowed them to cross the Columbia River on dry land (Clark, 1952; Lawrence and Lawrence, 1958; O’Connor, 2004).

Previously published maps of landslides on the north side of the western Columbia Gorge (Waters, 1973; Palmer, 1977; Walsh and others, 1987; O’Connor and Burns, 2009) are small scale and reconnaissance in nature. This early mapping identified four major landslide areas between the towns of Washougal and White Salmon, Washington (fig. 3): the Washougal landslide area $\left(\sim 13 \mathrm{~km}^{2}\right)$; the Skamania landslide area $\left(\sim 47 \mathrm{~km}^{2}\right)$; the Cascade landslide area, also called the Bonneville landslide area in some references $\left(\sim 36 \mathrm{~km}^{2}\right)$; and the Wind Mountain landslide area $\left(\sim 26 \mathrm{~km}^{2}\right)$. In the map area, these landslide areas are termed landslide complexes, because they include multiple individual landslides. Only the Skamania and Cascade landslide complexes are included in this map, due to lidar coverage limitations. Wise (1961) subdivided the Cascade landslide complex into four individual landslides: the Carpenters Lake (slide 305), Bonneville (slide 301), Red Bluffs (slide 302), and Mosley Lakes landslides. Randall (2012) ascertained that the Mosley Lakes landslide was simply terrain within the Red Bluffs landslide deposit, not a separate or reactivated landslide. However, another part of the Red Bluffs landslide body has been reactivated and is here termed the Crescent Lake landslide. 


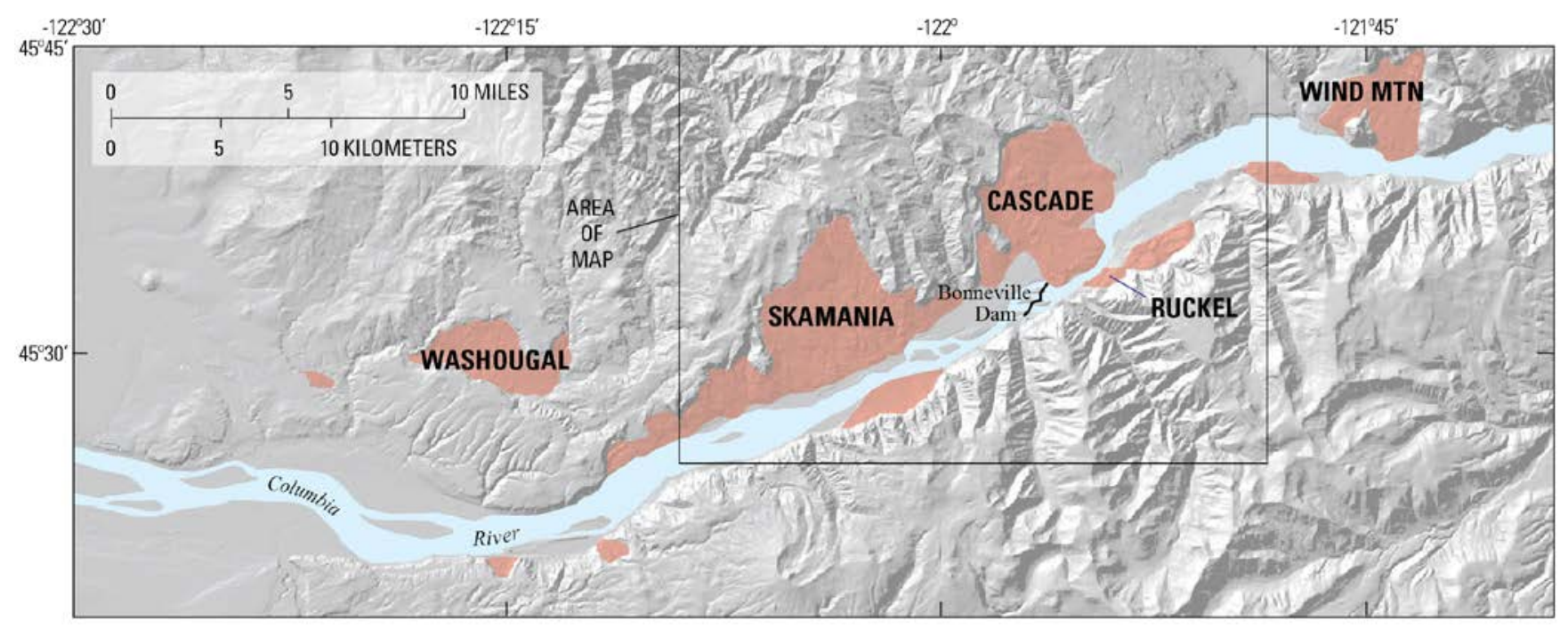

Figure 3. Previously mapped landslide complexes (brown) and known unstable terrain in the Columbia Gorge, Skamania County, Washington, including the Ruckel Landslide across the river in Oregon. Figure modified from O'Connor and Burns (2009), which was based on map shown in Palmer (1977).

\section{Methodology}

\section{Landslide Identification and Mapping}

Landslides in this study have been mapped on the basis of geomorphic features characteristic of landslides (fig. 4) that are visible on 6-ft-resolution (1.83-m-resolution), bare-earth, shaded-relief, digital elevation models (DEMs) at the scale of 1:12,000 and derived from 2005 lidar imagery obtained from the Puget Sound Lidar Consortium (http://pugetsoundlidar.ess.washington.edu/). Readily identifiable landslide features on the lidar DEMs include headscarps, internal scarps, radial cracks and shear zones, concave slope depressions and grabens, back-rotated blocks, transverse cracks and ridges, and convex slope bulges and toes.

Mapping protocols recommended in Burns and Madin (2009) were followed as much as possible for identifying landslides on the lidar DEMs. Map layers used for maximum enhancement of landslide features included (1) a shaded-relief map with sun azimuths of $45^{\circ}$ and $315^{\circ}$ and a sun angle of $45^{\circ}$; (2) a gradational slope map with all slopes steeper than $45^{\circ}$ angles shown in dark gray; (3) a colored hillshade map to show relative elevation; and (4) contour lines. Layer transparencies were then adjusted for maximum clarity of features. To avoid obscuring the topographic features on the final map product, the colored elevation hill-shade layer, slope map, and contour lines were not used. Lidar mapping (T.C. Pierson) was augmented by field mapping of landslide deposits and bedrock (R.C. Evarts). The line work was then scanned and digitized using the ArcGIS ArcScan toolset, with landslide bodies and major scarps (both headscarps and shear-wall scarps) represented as separate polygons and with polygon attributes summarized in a landslide database (J.A. Bard). Google Earth imagery, river bathymetry, and historical photography predating Bonneville Dam were used to approximate the submerged landslide boundaries in the Columbia River reservoir upstream of Bonneville Dam. Google Earth images were also used in lieu of regular aerial photography and orthophoto maps to distinguish natural features from man-made features, as needed. 


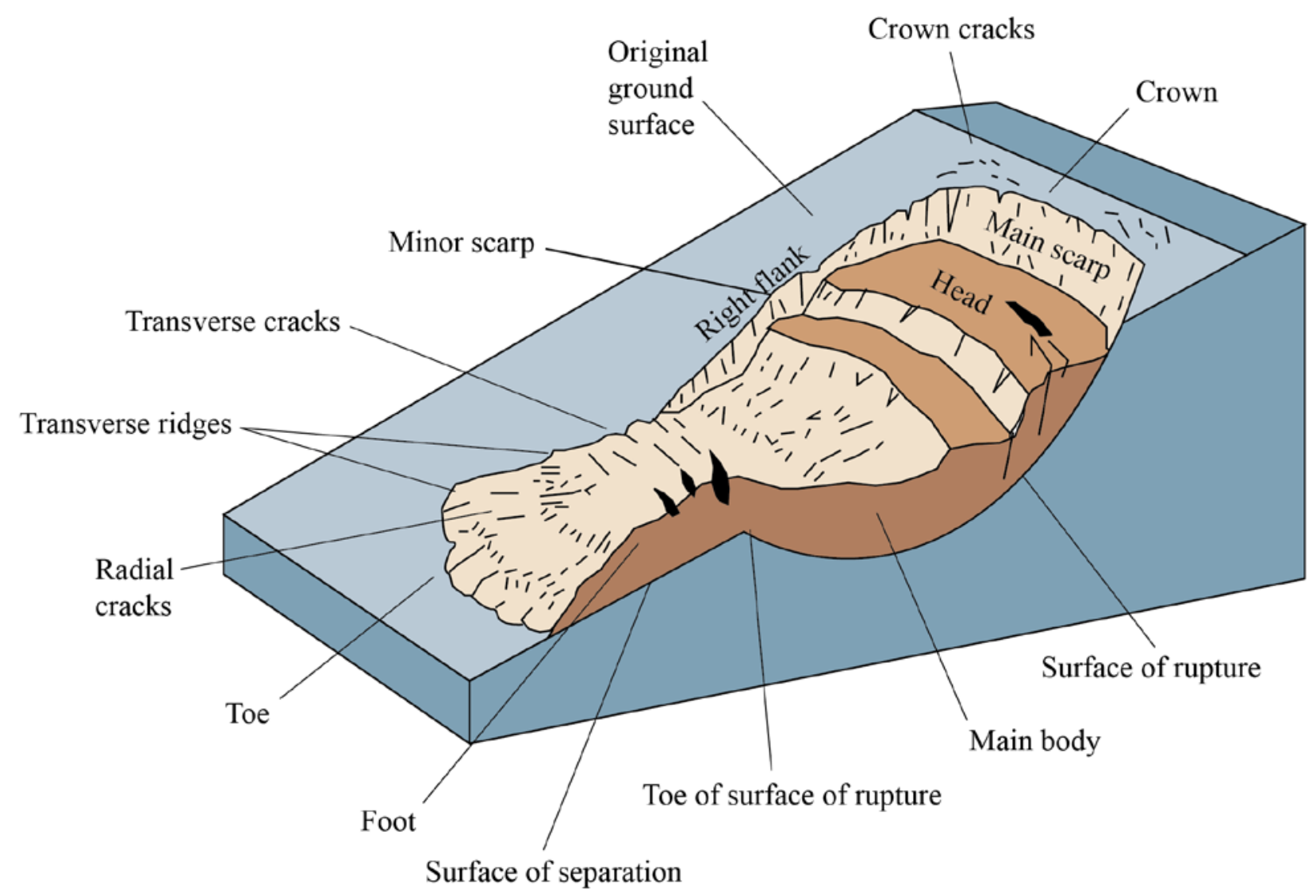

Figure 4. An idealized rotational landslide showing commonly used terms for various features. Figure from Highland (2004).

Landslides on this map differ from those shown on geologic maps, such as that of Wise (1970), because landslide maps show all parts of landslides, including headscarps, landslide deposit bodies, and terrain that had been covered by since-eroded slide debris. Most geologic maps portray only landslide deposits. Therefore the landslides on this map are larger than some previously mapped landslide deposits.

Not all features in the map area that are or could be landslides were mapped. Some features could have been old and degraded landslide scarps, but the associated landslide bodies were not identifiable. Amorphous lumps visible on the landscape were probably degraded landslide bodies, but their sources were not clear. These types of features were not mapped due to the uncertainty of their boundaries, but their presence suggests that the landslides mapped for this study represent only a minimum count of past landslides in this terrain. In addition, landslides smaller than $5,000 \mathrm{~m}^{2}$ in area were not mapped due to scale limitations.

\section{Landslide Numbering and Classification}

Each mapped landslide is assigned and labeled with a unique identification (ID) code, which allows it to be identified, both on the map and in the landslide data table (appendix and metadata at http://dx.doi.org/10.3133/sim3358). Landslide ID codes begin with the individual landslide number: old landslides are assigned numbers in the 100s; intermediate-age landslides are given numbers in the 200s; and recent landslides have numbers in the 300s. ID numbers are assigned by landslide area; landslide areas are progressively smaller as numbers increase away from 100, 200, and 300. Definable landslide 
scarps and bodies are mapped as separate polygons where possible. Relatively small internal scarps and lateral shears are depicted as lines. Landslide type and movement class are also designated by a code (table 1), simplified from the codes used by Burns and Madin (2009). Attributes of individual landslides are summarized in the landslide data table (appendix at http://dx.doi.org/10.3133/sim3358). Table 2 includes a sample row from the appendix to show how the columns are organized and labeled.

Table 1. Types of landslide movement interpreted from topography in western Columbia Gorge, Skamania County, Washington, and movement codes used in database (modified from Burns and Madin, 2009).

\begin{tabular}{llc}
\hline \multicolumn{1}{c}{ Type of movement } & \multicolumn{1}{c}{ Movement class } & Movement code \\
\hline Slide & Landslide-rotational & LS-R \\
& Landslide-translational & LS-T \\
Flow & Debris flow & DFL \\
& Earth flow & EFL \\
Fall & Rock fall & RF \\
Complex movement & Composite landslide & LS-C \\
\hline
\end{tabular}

Table 2. Example row of landslide attributes shown in the landslide data table (appendix at http://dx.doi.org/10.3133/sim3358).

[Slide ID, unique landslide identification number. Slide part, part of landslide (polygon on map). Mapped scarps include headscarps and internal scarps that are relatively large compared to size of landslide. Age, relative landslide age. Current activity is noted. Movement history, inferred movement history. Number parent slides, number of parent landslides if reactivated. Parent slides, slide ID of parent landslide(s) involved in reactivation. Slide type, type of landslide from categories shown in table 1. Abbreviations defined in table 1. Slide name, landslide name if it is named. Landslide complex, name of complex, if it is named. Notes, pertinent additional information. Area_sqkm and Area_sqm, mapped area (polygon) in square kilometers and square meters]

\begin{tabular}{|c|c|c|c|c|c|c|c|c|c|c|c|}
\hline $\begin{array}{l}\text { Slide } \\
\text { id }\end{array}$ & $\begin{array}{l}\text { Slide } \\
\text { part }\end{array}$ & Age & $\begin{array}{c}\text { Movement } \\
\text { history }\end{array}$ & $\begin{array}{c}\text { Number } \\
\text { parent } \\
\text { slides }\end{array}$ & $\begin{array}{l}\text { Parent } \\
\text { slides }\end{array}$ & $\begin{array}{l}\text { Slide } \\
\text { type }\end{array}$ & Slide name & $\begin{array}{l}\text { Landslide } \\
\text { complex }\end{array}$ & Notes & Area_sqm & Area_sqkm \\
\hline 309 & Body & $\begin{array}{l}\text { Recent/ } \\
\text { active }\end{array}$ & Reactivated & $\geq 2$ & 301,305 & LS-T & $\begin{array}{l}\text { Hot Springs } \\
\text { Slide }\end{array}$ & Cascade & $\begin{array}{l}\text { Slide movement } \\
\text { in } 1999 \text { caused } \\
\text { gas pipeline } \\
\text { rupture and } \\
\text { fire. }\end{array}$ & 0.4858 & 485,778 \\
\hline
\end{tabular}

Reactivation of older landslides is inferred from the crosscutting relation of landslide boundaries or from the location of slides entirely within the boundaries of larger slides. If a landslide occurs on terrain that has no evidence of prior movement, it is classified as a "first-generation" landslide. If its boundaries border on terrain showing evidence of prior movement, it is classified as a "reactivated landslide." Studies show that sites of past slope instability can be at risk for future landslide movement (Carrara and others, 1995; Van Den Eeckhaut and others, 2009; Burns and Madin, 2009).

\section{Landslide Ages}

Most of the mapped landslides are assigned relative ages (in calendar years) on the basis of the appearance of the landslide surfaces, as defined by surface roughness (the sharpness and textural definition of surface features) that is visible on the high-resolution lidar DEMs; the degree of surface drainage development; and the presence or absence of erosional or depositional features imparted by dozens of catastrophic glacial floods that occurred between about 14,500 to 22,000 calendar years ago, the largest of which reached inundation levels of slightly more than $200 \mathrm{~m}$ (700 ft) altitude in this part of the gorge (O’Connor and Baker, 1992; O’Connor, 1993; Benito and O’Connor, 2003; O’Connor, 2009). Relative roughness of the terrain is visually calibrated with (1) the appearance of surfaces of currently active landslides and two dated slides younger than 1,000 years in the map area, (2) surfaces of dated landslides in other areas (Bell and others, 2012; LaHusen and others, 2015), and (3) degrees of degradation (smoothing) of dated, vertical-offset earthquake fault scarps (Wallace, 1977; Bucknam and 
Anderson, 1979), with degrees of degradation subjectively corrected for geology, vegetation, and climatic setting. Based on these criteria, we define three categories of relative landslide age-recent, intermediate-age, and old.

- Recent landslides, assumed to be less than 1,000 years old, have sharply defined headscarps, internal scarps, lateral shear ridges, and toe lobes with a high level of textural resolution of the morphologic features on their surfaces. The slide bodies are not incised by gullies or stream channels. In the map area, dated slides with such sharply defined features are up to 600 years old. In semi-arid regions of the U.S., scarps can remain sharp and uneroded for several thousand years (Wallace, 1977; Bell and others, 2012). However, given the wet climate and dense vegetation of the western Columbia Gorge, we assume ages of about 1,000 years or less for such sharp and fresh-looking surface morphologies.

- Intermediate-age landslides have slightly rounded and eroded surficial features and are assigned ages of about 1,000 to 15,000 years. Streams crossing these landslides have a low to moderate amount of incision, but the lower parts of landslide bodies do not appear to have been eroded by the Missoula floods. However, some uneroded landslides may have been triggered (or reactivated) by toe erosion during the last of these catastrophic floods and could be as old as the latest flood without showing flood scour (Randall, 2012).

- Old landslides have moderately to highly smoothed and eroded features are inferred to be older than about 15,000 years, and some are probably significantly older than this. The degree of smoothing and rounding of surficial features is extreme in some cases, the features being almost completely smoothed out. Beyond some unknown age, very old landslide deposits are likely indistinguishable from the extensively weathered and eroded surfaces of hillslopes.

Only two prehistoric landslides have been dated: the Bonneville and Red Bluffs landslides (slides 301 and 302), located in the Cascade landslide complex. In the first case dating gives the approximate time of occurrence; in the second it provides a limiting minimum age.

The Bonneville landslide has been dated by a combination of radiocarbon dating, dendrochronology, and lichenometry. Initial dating efforts placed its year of occurrence originally at about A.D. 1250 (Lawrence and Lawrence, 1958) and then between A.D. 1500 and 1760 (Reynolds, 2001; Schuster and Pringle, 2002). However, more recent tree-ring dating of living trees on the landslide demonstrated that emplacement had to have occurred prior to about A.D. 1550 (Weaver and Pringle, 2003). Subsequently, the technique of wiggle-match radiocarbon dating of tree-ring sequences (Galimberti and others, 2004) was used to acquire a more precise age range (O’Connor, 2004; Reynolds and others, 2015) from wood obtained from a log entrained in the landslide deposit and from two standing dead trees that had been growing along the banks of the Columbia River but had been drowned in the lake formed by blockage of the river by the landslide. Ring patterns show that all three trees were killed in the same year, very likely between A.D. 1421-47 (95 percent confidence interval) and almost certainly between 1416-52 (99.7 percent confidence).

The Red Bluffs landslide has crosscutting morphologic features suggesting a younger age than that of the Bonneville landslide. The Red Bluffs landslide body shows an onlapping relation with the adjacent Bonneville landslide deposit (map), indicating that at least some of the movement of the Red Bluffs landslide occurred after the main part of the Bonneville landslide deposit was emplaced. In addition, the steep exposed headscarp of the Red Bluffs landslide is generally higher (less buried in talus) and less vegetated than that of the Bonneville slide (cover photo; map), although they are both at about the same altitude and were originally of similar heights. Although both landslides are estimated to be about the same volume $\left(\sim 1 \mathrm{~km}^{3}\right)$, the width of the Bonneville headscarp is narrower than the Red Bluffs headscarp (2.1 km vs. $3.7 \mathrm{~km})$, suggesting that part of the original Bonneville headscarp may 
have been part of terrain immediately to the east and was subsequently incorporated into the Red Bluffs landslide.

Limited radiocarbon dating suggests a post-Bonneville age for a least the downslope part of the Red Bluffs landslide deposit near the toe. A minimum-age date, obtained from the bottom $2 \mathrm{~cm}$ of a 30cm-thick, peat-like organic layer that had accumulated in a closed depression directly on the surface of the landslide deposit near Skamania Lodge (map) and constrained by the age of a cored living tree farther upslope on this deposit surface, gives a $2 \sigma$ calibrated age range of A.D. 1670-1780. This age marks the start of recolonization by vegetation on the landslide toe, which for Douglas fir forest can take one to several decades on disturbed land surfaces in this region (Pierson, 2007). Another minimum-age date on the innermost rings of a tilted and fire-charred standing dead tree on the landslide deposit surface gives a $2 \sigma$ calibrated age range of A.D. 1618-1895 (P.T. Pringle, unpub. data, 2014)—a date that permits but does not require post-Bonneville landslide emplacement, because this tree could have started growing long after slide emplacement. This latter age range is narrowed further by a ring-count age of a 1.3-m-diameter living Douglas fir growing near the fire-charred snag, which requires the landslide deposit at this location to have been emplaced prior to A.D. 1810. Significantly decayed nearby Douglas fir stumps, also about $1.3 \mathrm{~m}$ in diameter and probably logged in the mid-20th century as inferred from the degree of decay (Storaunet and Rolstad, 2002), push the 1810 minimum age back another 40 or 50 years at least, requiring that the dated tree had to have started growing prior to A.D. 1760-1770. Thus on the basis of (1) limited radiocarbon dating, (2) apparent onlapping of the Red Bluffs deposit onto the Bonneville deposit, and (3) truncation of linear features in the Bonneville deposit by the Red Bluffs deposit, we tentatively conclude that most or all of the Red Bluffs landslide was emplaced after the Bonneville landslide. The minimum-age radiocarbon dates are permissive of emplacement as much as 200 to 300 years after the Bonneville landslide, possibly at the time of the last Cascadia Subduction Zone earthquake in A.D. 1700 (Atwater and others, 2015), but additional dating of this landslide is needed.

Some landslides in the map area are currently active (in 2015) or have been active within the last 20 years. These active landslides have been identified from direct measurements and field observations, news reports, and geotechnical reports, and they are designated as active on the map and in the landslide data table (appendix). These unstable areas include a large reactivated slide within the Red Bluffs landslide, here named the Crescent Lake landslide (slide 303), and a reactivated part of the Carpenters Lake landslide (slide 305), here named the Hot Springs landslide (slide 308) (Federal Register, 1999; Pierson and Lu, 2009). Other parts of the lower Bonneville and Red Bluffs landslides were reported to have moved in the 20th century, with some movement likely induced by highway and railroad construction (Palmer, 1977; Schuster and Pringle, 2002). It is likely that recent movement of the Hot Springs landslide caused a rupture and explosion of the 26-inch Northwest Pipeline Corp. natural gas pipeline on February 26, 1999 (Federal Register, 1999). Active landslides in other parts of the map area are also causing damage to infrastructure (unpublished Bonneville Power Administration field trip reports, 2010). The Crescent Lake landslide, $7.5 \mathrm{~km}^{2}$ in area, is moving at an average rate of 11-18 $\mathrm{cm} / \mathrm{yr}$ (T.C. Pierson, unpub. GPS data, 2009-2012) and possibly as fast as $25 \mathrm{~cm} / \mathrm{yr}$ (Pierson and Lu, 2009). Monitoring of the natural gas pipeline buried in the landslide toe has shown downslope movement to be occurring since at least 1979, and earlier unmonitored movement caused ruptures of the pipeline in 1972 and 1978 (Braun and others, 1998). Activation of Crescent Lake landslide through loading at its head by recent rock falls has been suggested (Randall, 2012) but is unlikely, due to infrequent rock-fall occurrence in contrast to decades of steady seasonal movement, the relatively small size of rock falls in relation to the slide, and emplacement of recent rock falls only at the far western edge of the slide head, where the added mass would have minimal effect. 


\section{Mapping Results and Conclusions}

Summarized results of landslide mapping (table 3; appendix) reveal that $140.9 \mathrm{~km}^{2}$ (64 percent) of the map area consist of at least 215 individual landslides, most (62 percent) of which are translational landslides or composite slides with some apparent translational movement. Mapping for this study expanded the area of known unstable terrain in the map area by 56 percent (fig. 5). Although only two of the prehistoric landslides have absolute dates, movement histories of all the mapped landslides likely span at least several tens of thousands of years. About two thirds of the identified landslides (77 percent of the mapped landslide area) are estimated to have moved in the last 15,000 years, and almost a quarter of the mapped slides (36 percent of mapped landslide area) are less than about 1,000 years old (fig. 6).

Much of the terrain in the map area has a history of repeated instability (table 3; fig. 7). About 42 percent of the mapped landslides (about two thirds of the landslide area) have remobilized parts of older landslides, and 16 percent of all the mapped slides (37 percent of the reactivated slides) involve terrain that has moved at least twice before. Many but not all of these newly recognized landslides occur within the massive Skamania and Cascade landslide complexes, which are far more complicated, involve more episodes of reactivation, and include more recent movement than previously realized.

Table 3. Summary of total areas for different categories of landslides, western Columbia Gorge, Skamania County, Washington. See appendix for landslide data table (http://dx.doi.org/10.3133/sim3358).

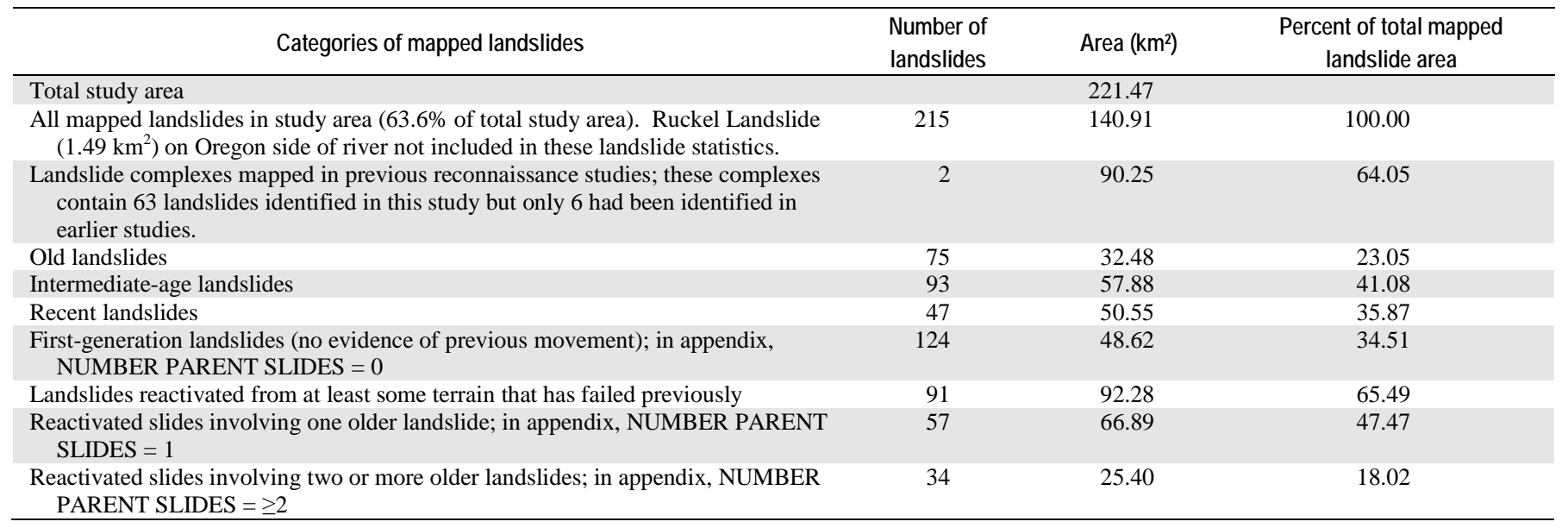

Data from InSAR, precision surveys, pipeline strain gauges, and GPS, plus historical records, indicate that 12 of the landslides mapped as recent (slides 303, 309, 312, 315, 320, 322, 330, 333, 334, 340, 343, and 345) are currently active or have moved within the last two decades (Braun and others, 1998; Biever, 1999; Federal Register, 1999; Schuster and Pringle, 2002; Pierson and Lu, 2009). One of these active landslides, the Maple Hill landslide, exhibits multiple failure planes. It is relatively thin (8 to $12 \mathrm{~m}$ ) and is sliding mainly along a weak clayey zone at the soil/bedrock (Eagle Creek Formation) interface. However, deeper failure planes are inferred from clayey, slickensided zones found mostly in clayey siltstone and claystone units within the Eagle Creek Formation at depths of about 15, 18, 19, 20, 22, 24, and $32 \mathrm{~m}$ below the landslide surface. Small-magnitude inclinometer deflections at 17 and $20 \mathrm{~m}$ depth suggest that some of these potential failure planes have very low factors of safety.

The only major town in this map area, Stevenson (the Skamania County seat), is built almost entirely on landslides, most of which have had two or more previous episodes of movement. Several landslides in Stevenson are active, such as the Piper Road landslide (fig. 8), a landslide that reactivated parts of slides 333 and 334 in 2007 and claimed one house. Previous reconnaissance mapping in the Stevenson area classified the terrain as an exposed failure plane of a single landslide from which the 
slide debris had been largely removed (Wise, 1970; Randall, 2012). However, several lines of evidence now indicate that what was thought to be one landslide beneath Stevenson is actually a complex of multiple active and inactive translational landslides. The evidence includes documented downslope movement, well-defined landslide toes and headscarps visible on lidar imagery (map), multiple failure planes and limited creeping movement identified in boreholes (Biever, 1999), large basalt boulders and deeply weathered blocks of lower Eagle Creek Formation incorporated into slide debris (Biever, 1999; mapping), and a vertical section of landslide debris and slide plane freshly exposed along Rock Creek (fig. 8). Failure planes within the Stevenson landslide complex appear to occur on the top surface of the Eagle Creek Formation, at several levels within the upper Eagle Creek volcaniclastics, on the upper surface of the lower Eagle Creek Formation, and at the contact between lower Eagle Creek gravels and underlying Weigle formation (Biever, 1999; mapping).

The Cascade and Skamania landslide complexes contain the highest density of landslides in the map area, and the Cascade complex contains the largest area of recent and currently active landslides (figs. 5, 6). Our mapping confirms Randall's (2012) conclusion that the previously mapped Mosley Lakes landslide (Wise, 1961) is actually a part of the Red Bluffs landslide. What apparently was thought to be the headscarp for the Mosley Lakes landslide is actually part of the toe of the Crescent Lake slide (slide 303). In the western part of the Cascade landslide complex, we interpret the septum of raised terrain that separates the Bonneville and Carpenters Lake landslides (slides 305 and 301) in earlier reconnaissance maps to be part of the Bonneville landslide, although it could be part of a block that moved independently from the main part of the slide. The septum had been previously interpreted as inplace stable terrain (Wise, 1961, 1970; Palmer, 1977; Randall, 2012), but two lines of evidence bring this interpretation into question. First, a series of fresh, parallel, internal scarps in the septum (visible on lidar imagery) suggests fracturing and partial extension to the southeast. Second, the altitude of the contact between the Columbia River Basalt Group and Eagle Creek Formation in the septum is $730 \mathrm{~m}$ lower than at Table Mountain immediately to the north in the headscarp of the slide. The lava flow that overlies Eagle Creek beds in the septum is not exposed in the headwall at Table Mountain, but across the Columbia River in Oregon it directly underlies the lowest flow exposed in the headscarp. The elevation difference between the two flows is much greater in Washington, indicating that the septum has been dropped down from its original position. The headscarp of the Carpenters Lake landslide forms the west wall of the septum, and the toe of the Carpenters Lake landslide appears to overlap the toe of the Bonneville landslide, suggesting that movement of the Carpenters Lake landslide postdates movement of both the septum and the main part of the Bonneville landslide.

An historically active landslide on the Oregon side of the river, the Ruckel landslide (fig. 5; slide 401), is located directly across the Columbia River from the toe of the Bonneville landslide deposit, adjacent to the town of Cascade Locks. It is clearly visible on lidar imagery (map) and is the only landslide mapped on the Oregon side, because it had been suspected by some of being a reactivated part of the original toe of the Bonneville landslide that had run up on the Oregon shore and subsequently undergone slumping back toward the river (Reynolds, 2001; Schuster and Pringle, 2002). It was actively creeping from the start of portage railway construction in 1873 until 1924, when movement was halted (at least through 1971) by the installation of horizontal drains (USACE, 1971). 


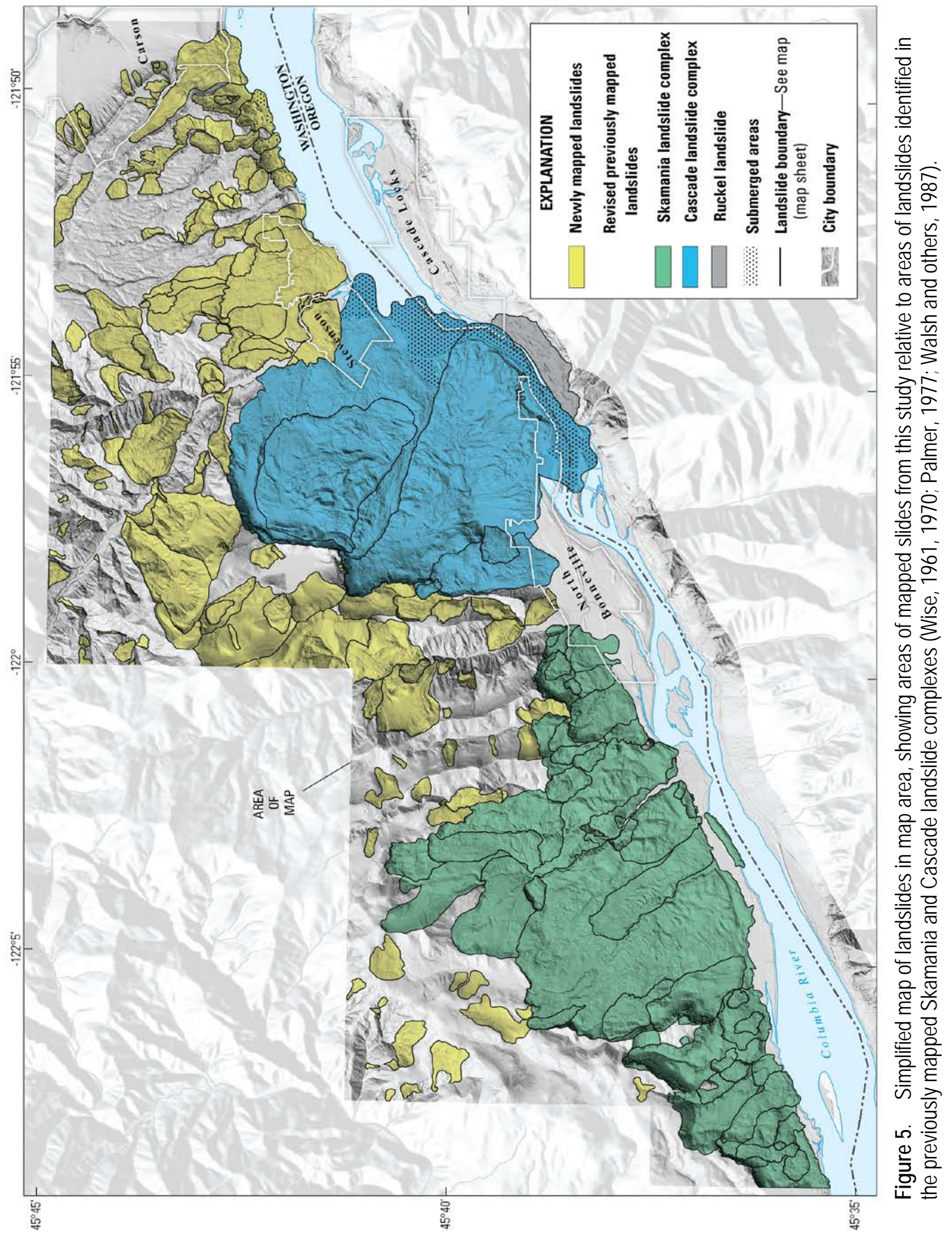




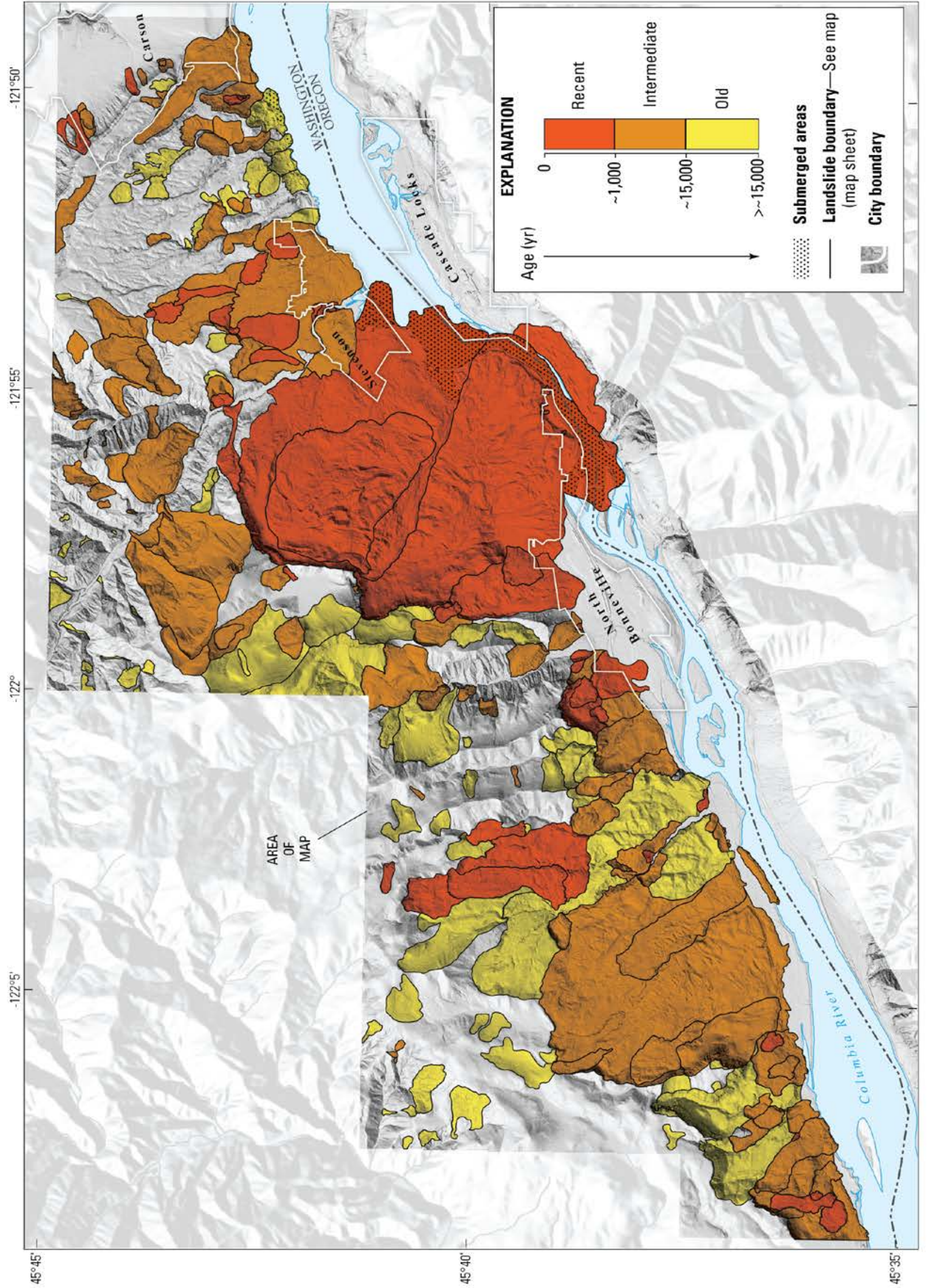

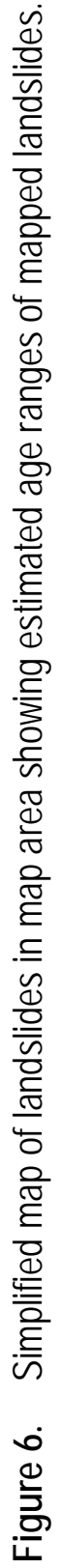




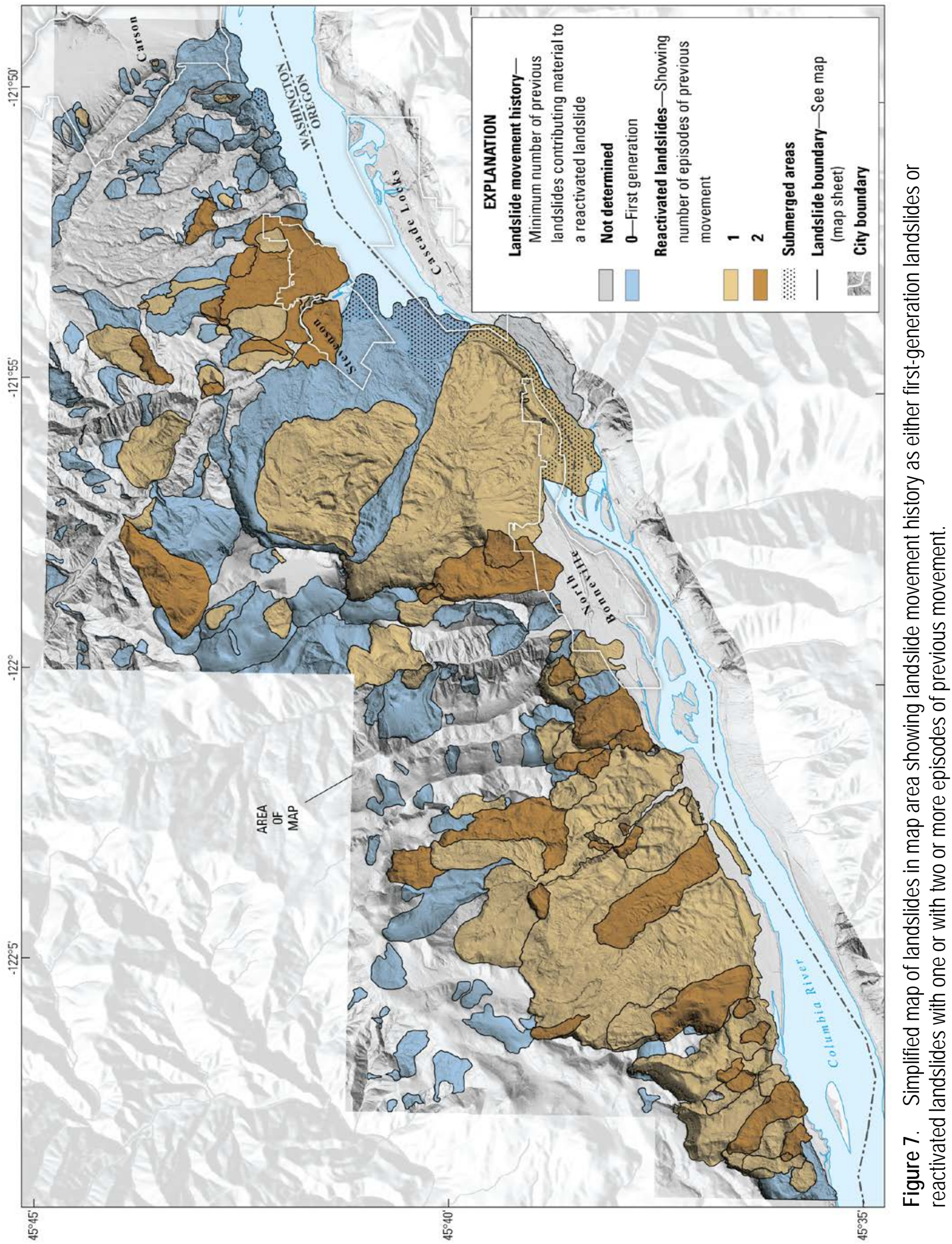



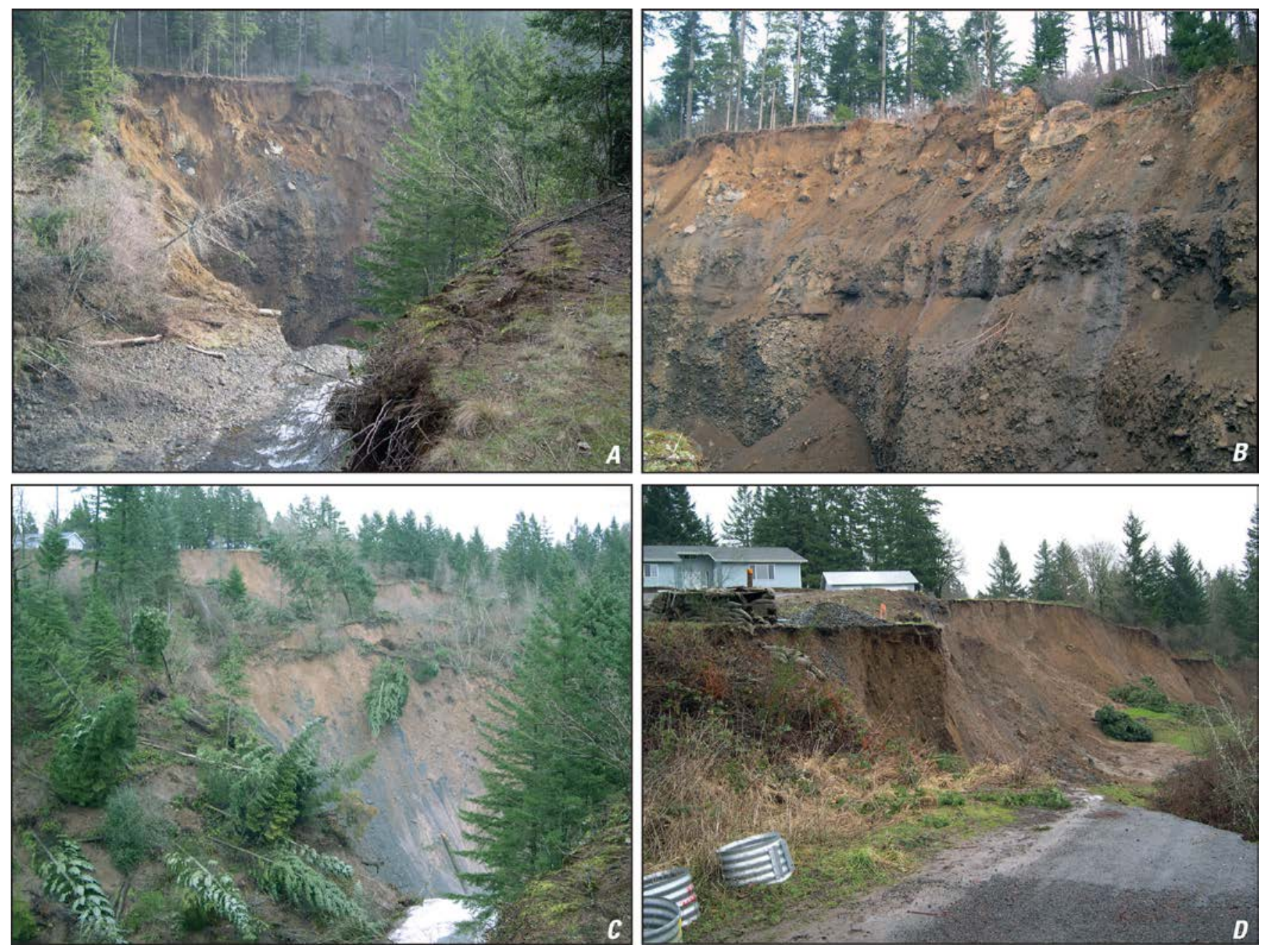

Figure 8. Different views of the Piper Road landslide (also called the Rock Creek landslide), which involved parts of slides 333 and 334 and which is a reactivated part of the larger Stevenson landslide (slide 202). Reactivation began in February 2007 and continued intermittently for a several years. A, Vertical face downstream of Rock Creek waterfall; creek is shown in lower center flowing at the top of the falls on an indurated volcaniclastic fluvial gravel of the lower Eagle Creek Formation. Orange-brown upper part of vertical face in this photograph (matrix-supported bouldery diamict) is older Stevenson landslide deposit before it became part of the Piper Road landslide; photo was taken just as movement was starting on February 6, 2007. B, Bluff along Rock Creek on February 6, downstream of vertical face shown in A. The section clearly shows a vertical section of the Stevenson landslide (slide 202), the upper orangebrown unit, which here is relatively thin (7-8 $\mathrm{m}$ thick). It forms a sharp contact with the underlying Eagle Creek gravel along a failure plane. Distinct bedding-parallel planar zones shown within the gravel a few meters below the upper contact may also act as failure planes. $C$, The actively moving Piper Road landslide was sliding at an estimated rate of several tens of centimeters per minute as this photograph was taken on February 16, 2007, at 10:08 a.m. Photograph was taken from same perspective as the photo in A. House visible in upper left was destroyed a few weeks later when the headscarp retrogressed under it. $D$, Headscarp of the Piper Road landslide on February 16, 2007. House is same one visible in upper left of $C$. Photographs by T.C. Pierson. 
The Ruckel landslide was interpreted by consultants for the U.S. Army Corps of Engineers (USACE, 1971) to be a landslide originating from the Oregon shore. This interpretation is supported by field checking for this study, which revealed that the lower part of the Ruckel landslide, at the same elevation as the Bonneville landslide toe, is composed of highly fractured, back-rotated, but relatively coherent bedrock blocks of large size (10-100 m across). We encountered blocks of Eagle Creek Formation on the eastern part of the slide and basalt in the central and western parts of the slide). The presence of large landslide blocks with minimal interstitial matrix suggests a relatively short transport distance. If the Ruckel landslide originally had been part of the Bonneville landslide toe, we would expect to find well-mixed slide debris composed of dispersed clasts and blocks suspended in a poorly sorted matrix of crushed fine-grained rock debris and entrained sediment-the type of material found immediately across the river (Palmer, 1977), which results from extreme shearing and rapid transport over 6-7 km horizontal distance. Although bedrock lithologies on both sides of the river are essentially the same, the better explanation for the emplacement of massive and largely intact blocks of bedrock in the Ruckel landslide would be down-dropping and rotational sliding from the steep slopes on the Oregon side of the river, rather than much longer, avalanche-style, subhorizontal transport from the Washington side. Yet the position of the Ruckel landslide directly across from the toe of the Bonneville landslide suggests a causal connection between the two landslides. Overtopping of the Bonneville landslide blockage by water impounded upstream would have occurred at the point of lowest elevation on the natural dam or on the abutting Oregon shore-a point most likely at or adjacent to the toe. Subsequent downcutting by the Columbia River at this point (diverting the river about $1 \mathrm{~km}$ south of its prelandslide course) had to have undercut the steep slope on the Oregon shore to some degree, very likely contributing to initiation of the Ruckel landslide.

A number of the landslides in the map area are quite large. The horizontal runout distances of the recent Bonneville and Red Bluffs landslides are between 6 and $7 \mathrm{~km}$, and the ratios of maximum vertical fall height to maximum horizontal runout $\left(\mathrm{H}_{\max } / \mathrm{L}_{\max }\right)$ for these two large landslides are 0.15 and 0.14 , respectively. Assuming an average thickness of roughly $75 \mathrm{~m}$ for both the Bonneville and Red Bluffs landslides (based on the Bonneville landslide cross section in Palmer, 1977) and using their measured areas (appendix), the volumes of these two landslides are estimated to be about $1 \mathrm{~km}^{3}$ each. The runouts and $\mathrm{H} / \mathrm{L}$ ratios for both landslides are typical for nonvolcanic landslides of this size and do not necessarily indicate excessive mobility or require high emplacement velocities (Legros, 2002). Some slow-moving landslides such as the Slumgullion landslide in Colorado (Coe and others, 1998) can have comparable mobility indices relative to volume (Legros, 2002). However, the splayed planview shape of the lower part of the Bonneville landslide deposit, combined with an inferred horizontal to uphillsloping slide plane in this zone, suggests that at least this landslide was emplaced rapidly-meters to tens of meters per second. Some older landslides in the map area may have been as large (or larger, slide 201 for example) and as rapid, but later partial reactivation and erosion of the toes obscures the original deposit geometries.

Stability analyses of the potential for future large landslides in the western Columbia Gorge have, to our knowledge, not been carried out. In particular, the potential for earthquake-induced ground accelerations to destabilize the terrain behind the 100- to 350-m-high headscarps of the Bonneville and Red Bluffs landslides, or to reactivate certain seasonally active or dormant landslides (Schulz and Wang, 2014), has not been investigated. With the probability of a magnitude 9 Cascadia Subduction Zone (CSZ) earthquake occurring within the next 50 years calculated at about 1 chance in 10 (Petersen and others, 2002; Goldfinger and others, 2012), such investigations are warranted. Preliminary radiocarbon dating of the Red Bluffs landslide cannot exclude the possibility that this failure was triggered by the last CSZ earthquake in A.D. 1700. If a large failure were to occur in this section of the Columbia Gorge during the next CSZ earthquake, there could be serious hazardous consequences. Depending on the size, 
speed, and runout distance of any future landslide, vulnerable infrastructure could include a major natural gas pipeline; high-voltage power transmission lines from Bonneville Dam; road, rail, and river barge transportation corridors on both sides of the river; and Bonneville Dam itself.

\section{Mapping Confidence and Limitations}

Confidence in interpretation of landslide terrain derives from the experience of the mapper in recognizing landslide features, the adequacy of applied map layers to allow landslide features to be visible, the sharpness of the surface morphology of the landslide features, the scale of the landslide features relative to the resolution of the DEMs, and the thoroughness of field-checking of landslide deposits. Note that topographic expressions of landslides shown on this hillshade base map may not all be convincing, because landslide recognition was based on the application of various DEM sun angles, shadings based on slope angle and elevation, and contour lines that are not all shown on the final map. Landslide aspect greatly affects the visibility of some landslide features with a particular sun angle applied to the topography.

Recent landslides in this study are mapped with high confidence, because all mapped landslides had multiple and clearly visible morphologic features characteristic of landslides. Some mapped boundaries of recent landslides are approximate where landslide deposits are not currently exposed. Such areas were mapped on the basis of (1) old pre-dam aerial photographs that show landslide deposits in areas now submerged by the Bonneville reservoir pool, and (2) where drill cores from exploratory borings obtained prior to dam construction revealed landslide deposit beneath the surface. Intermediateage landslides are mapped with moderate to high confidence, subject to the number and distinctness of visible features. Old landslides are mapped with moderate confidence, because visible features and boundaries are moderately to highly muted and smoothed over.

Some possible landslides were not mapped because confidence was low. These features include areas where the boundaries of suspected old landslides could not be delineated; small areas within larger landslides where local movement could have been related to emplacement of the larger slide; and areas that were too small to show well at the scales utilized in this report. Despite the good resolution of the lidar DEMs used in this study (6 ft/1.83 m), landslides smaller than about 5,000 $\mathrm{m}^{2}$ were not delineated. In addition, many of the steep creeks show evidence of debris flows, but only the largest and most prominent of these have been mapped.

This study utilized high-resolution lidar imagery from 2005 that far surpassed previously available imagery in showing landslide locations, and it followed the latest landslide-mapping protocol of Burns and Madin (2009). The map, nevertheless, has limitations. Most of the landslides were located using aerially acquired remote sensing data, with limited field mapping of deposits and field checking. Furthermore, the map represents only a "snapshot" of the terrain in time, and other slope failures have occurred since 2005. Therefore, this map should be used as a regional guide in locating potentially unstable terrain and should not be used as a substitute for site-specific engineering studies.

\section{Digital Maps and Supplemental Material}

ArcGIS shape files of the landslides in this publication, together with relevant map overlays, can be found and downloaded at http://dx.doi.org/10.3133/sim3358. Also available from this website is the landslide data table (appendix and digital database) that includes the attributes for all the mapped landslides. The database was compiled using ArcGIS version 10.0 (Personal Geodatabase format). ArcGIS-compatible software is required to use the files of this database. 


\section{Acknowledgments}

We thank David Ramsey and Robert Nicholson for help in compiling the landslide data; Patrick Pringle for helpful discussions and sharing unpublished data on the age of the Bonneville landslide; David Scofield for providing unpublished U.S. Army Corps of Engineers reports and data; William Burns, Rex Baum, David Ramsey, and Patrick Pringle for technical reviews of the map and the report; and numerous other colleagues for fruitful discussions about these landslides. We also thank staff from Skamania County, Williams Pipeline Co., and Bonneville Power Administration for providing information about currently active landslides in the map area.

\section{References Cited}

Atwater, B.F., Musumi-Rokkaku, Satoko, Satake, Kenji, Tsuji, Yoshinobu, Ueda, Kazue, and Yamaguchi, D.K., 2015, The orphan tsunami of 1700-Japanese clues to a parent earthquake in North America (2nd ed.): Seattle, University of Washington Press, U.S. Geological Survey Professional Paper 1707, 135 p., https://pubs.er.usgs.gov/publication/pp/1707.

Bell, Rainer, Petschko, Helene, Röhrs, Matthias, and Dix, Andreas, 2012, Assessment of landslide age, landslide persistence and human impact using airborne laser scanning digital terrain models: Geografiska Annaler, Series A, Physical Geography, v. 94, p. 135-156.

Benito, Gerardo, and O’Connor, J.E., 2003, Number and size of last-glacial Missoula floods in the Columbia River valley between the Pasco Basin, Washington, and Portland, Oregon: Geological Society of America Bulletin, v. 115, p. 624-638.

Biever, M.P., 1999, Geotechnical investigation-Maple Hill landslide: Stevenson, Washington, unpublished report by Squier Associates, Inc. for Skamania County Deptartment of Public Works.

Brandt, A., ed., 2002, The journals of Lewis and Clark (abridged): Washington, D.C., National Geographic Adventure Classics, 445 p.

Braun, Jill, Major, Graeme, West, D.O., and Bukovansky, Michal, 1998, Geologic hazards evaluation boosts risk-management program for Western U.S. pipeline: Oil and Gas Journal, v. 96, issue 45 (11/9/98), 13 p.

Bucknam, R.C., and Anderson, R.E., 1979, Estimation of fault-scarp ages from a scarp-height-slopeangle relationship: Geology, v. 7, p. 11-14.

Burns, W.J., and Madin, I.P., 2009, Protocol for inventory mapping of landslide deposits from light detection and ranging (lidar) imagery: Oregon Department of Geology and Mineral Industries Special Paper 42, 30 p.

Campbell, N.P., and Bentley, R.D., 1981, Late Quaternary deformation of the Toppenish Ridge uplift in south-central Washington: Geology, v. 9, p. 519-524.

Carrara, A., Cardinali, M., Guzzetti, F., and Reichenbach, P., 1995, GIS technology in mapping landslide hazard, in Carrara, A., and Guzzetti, F., eds., Geographical information systems in assessing natural hazards: Dordrecht, the Netherlands, Kluwer Academic Publishers, p. 135-176.

Clark, E.E., 1952, The Bridge of the Gods in fact and fancy: Oregon Historical Quarterly, v. 53, p. 29-38.

Coe, J.A., Ellis, W.L., Godt, J.W., Savage, W.Z., Savage, J.E., Michael, J.A., Kibler, J.D., Powers, P.S., Lidke, D.J., and Debray, S., 2003, Seasonal movement of the Slumgullion landslide determined from Global Positioning System surveys and field instrumentation, July 1998-March 2002: Engineering Geology, v. 68, p. 67-101 doi:10.1016/S0013-7952(02)00199-0.

Denlinger, R.P., and O’Connell, D.R.H., 2010, Simulations of cataclysmic outburst floods from Pleistocene Glacial Lake Missoula: Geological Society of America Bulletin, v. 122, p. 678-689. 
Federal Register, 1999, Pipeline safety-Intent to approve project and environmental assessment for the Northwest Pipeline Corporation; Pipeline risk management project (Department of Transportation):

Federal Register, v. 64, no. 231 (Thursday, Dec. 2, 1999), p. 67603-4.

Fiske, R.S., Hopson, C.A., and Waters, A.C, 1963, Geology of Mount Rainier National Park, Washington: U.S. Geological Survey Professional Paper 444, 93 p.

Galimberti, M., Bronk Ramsey, C., and Manning, S.W., 2004, Wiggle-match dating of tree-ring sequences: Radiocarbon, v. 46, p. 917-924.

Goldfinger, C., Nelson, C.H., Morey, A.E., Johnson, J.E., Patton, J.R., Karabanov, E., Gutiérrez-Pastor, J., Eriksson, A.T., Gràcia, E., Dunhill, G., Enkin, R.J., Dallimore, A., and Vallier, T., 2012, Turbidite event history-Methods and implications for Holocene paleoseismicity of the Cascadia subduction zone: U.S. Geological Survey Professional Paper 1661-F, 170 p.

Haneberg, W.C., Cole, W.F., and Kasali, Gyimah, 2009, High-resolution lidar-based landslide hazard mapping and modeling, UCSF Parnassus Campus, San Francisco, USA: Bulletin of Engineering Geology and the Environment, v. 68, p. 263-276.

Highland, L., 2004, Landslide types and processes: U.S. Geological Survey Fact Sheet 2004-3072, 4 p. Holdredge, C.P., 1937, Final report on the Bonneville project, 1937: Unpublished report for U.S. Army Corps of Engineers, Portland District, 39 p.

Jutzeler, M., McPhie, J., and Allen, S.R., 2014, Facies architecture of a continental, below-wave-base volcaniclastic basin-The Ohanapecosh Formation, Ancestral Cascades Arc, Washington, USA: Geological Society of America Bulletin, v. 126, p. 352-376.

Keefer, D.K., 1984, Landslides caused by earthquakes: Geological Society of America Bulletin, v. 95, p. 406-421.

LaHusen, S.R., Duvall, A.R., Booth, A.M., and Montgomery, D.R., 2016, Surface roughness dating of long-runout landslides near Oso, Washington (USA), reveals persistent postglacial hillslope instability: Geology, v. 44, no. 5, doi:10.1130/G37267.1 (first published online December 22, 2015).

Lawrence, D.B., and Lawrence, E.G., 1958, Bridge of the Gods legend, its origin, history, and dating: Mazama, v. 40, no. 13, p. 33-41.

Legros, François, 2002, The mobility of long-runout landslides: Engineering Geology, v. 63, p. 301-331.

Nadim, Farrokh, Kjekstad, Oddvar, Peduzzi, Pascal, Herald, Christian, and Jaedicke, Christian, 2006, Global landslide and avalanche hotspots: Landslides, v. 3, p. 159-173.

O’Connor, J.E., 1993, Hydrology, hydraulics, and geomorphology of the Bonneville Flood: Geological Society of America Special Paper 274, 83 p.

O’Connor, J.E., 2004, The evolving landscape of the Columbia River Gorge: Oregon Historical Quarterly, v. 105, no. 3, p. 390-421.

O’Connor, J.E., 2009, Late Pleistocene Missoula floods-15,000-20,000 calendar years before present from radiocarbon dating [abs.]: Geological Society of American Abstracts with Programs, v. 41, no. 7, p. 169.

O’Connor, J.E., and Baker, V.R., 1992, Magnitudes and implications of peak discharges from glacial Lake Missoula: Geological Society of America Bulletin, v. 104, p. 267-279.

O’Connor, J.E., and Burns, S.F., 2009, Cataclysms and controversy-Aspects of the geomorphology of the Columbia River Gorge, in O’Connor, J.E., Dorsey, R.J., and Madin, I.P., eds., Volcanoes to vineyards-Geologic field trips through the dynamic landscape of the Pacific Northwest: Geological Society of America Field Guide 15, p. 237-251, doi:10.1130/2009.fld015(12).

Palmer, Leonard, 1977, Large landslides of the Columbia River Gorge, Oregon and Washington: Geological Society of America, Reviews in Engineering Geology, v. 3, p. 69-83, doi: 10.1130/REG3p69 
Petersen, M.D., Cramer, C.H., and Frankel, A.D., 2002, Simulations of seismic hazard for the Pacific Northwest of the United States from earthquakes associated with the Cascadia Subduction Zone: Pure and Applied Geophysics, v. 159, p. 2,147-2,168.

Pierson, T.C., 2007, Tree-ring dating of young lahar- and flood-deposit landforms downstream of volcanoes in the southern Washington and northern Oregon Cascades: Earth Surface Processes and Landforms, v. 32, p. 811-831.

Pierson, T.C., and Lu, Zhong, 2009, InSAR detection of renewed movement of a large ancient landslide in the Columbia River Gorge, Washington [abs.]: Geological Society of America Abstracts with Programs, v. 41, no. 7, p. 497.

Randall, J.R., 2012, Characterization of the Red Bluff Landslide, greater Cascade Landslide Complex, Columbia River Gorge, Washington: Portland, Oregon, Portland State University, M.S. thesis, 74 p.

Reidel, S.P., Martin, B.S., and Petcovic, H.L., 2003, The Columbia River flood basalts and the Yakima fold belt, in Swanson, T.W., ed., Western cordillera and adjacent areas: Boulder, Colorado, Geological Society of America Field Guide 4, p. 87-105.

Reiners, P.W., Ehlers, T.A., Garver, J.I., Mitchell, S.G., Montgomery, D.R., Vance, J.A., and Nicolescu, S., 2002, Late Miocene exhumation and uplift of the Washington Cascade Range: Geology, v. 30, p. 767-770.

Reynolds, N.D., 2001, Dating the Bonneville landslide with lichenometry: Washington Geology, v. 29, no. 3-4, p. 11-16.

Reynolds, N.D., O'Connor, J.E., Pringle, P.T., Schuster, R.L., and Bourdeau, A., 2015, Age of the Bonneville landslide and the drowned forest of the Columbia River, Washington, USA —From wiggle-match radiocarbon dating and tree ring analysis [abs.], in Symposium Steering Committee, eds., Program and abstracts of the 10th Washington Hydrogeology Symposium, http://depts.washington.edu/uwconf/wordpress/wahgs/past-symposia/.

Safran, E.B., Anderson, S.W., Mills-Novoa, Megan, House, P.K., and Ely, Lisa, 2011, Controls on large landslide distribution and implications for the geomorphic evolution of the southern interior Columbia River basin: Geological Society of America Bulletin, v. 123, p. 1851-1862; doi: 10.1130/B30061.1.

Schulz, W.H., 2007, Landslide susceptibility revealed by lidar imagery and historical records, Seattle, Washington: Engineering Geology, v. 89, p. 67-87.

Schulz, W.H., and Wang, Gonghui, 2014, Residual shear strength variability as a primary control on movement of landslides reactivated by earthquake-induced ground motion-Implication of coastal Oregon, U.S.: Journal of Geophysical Research Earth Surface, v. 119, p. 1617-1635.

Schuster, R.L., and Pringle, P.T., 2002, Engineering history and impacts of the Bonneville landslide, Columbia River Gorge, Washington-Oregon, USA, in Rybar, J., Stemberk, J., and Wagner, P., eds., Landslides-Proceedings of the First European Conference on Landslides, Prague, Czech Republic, 24-26 June, 2002: Lisse, Netherlands, Swets and Zeitlinger Publishers, ISBN $905809393 X$.

Storaunet, K.O., and Rolstad, J., 2002, Time since death and fall of Norway spruce logs in old-growth and selectively cut boreal forest: Canadian Journal of Forest Research, v. 32, p. 1801-1812.

USACE, 1971, Bonneville Dam, Columbia River, Washington-Oregon: Design memorandum no. 1, modification for peaking, Supplement no. 6, Oregon shore slide study: U.S. Army Corps of Engineers, Portland District, 138 p.

USACE, 1976, Second powerhouse railroad tunnel: U.S. Army Corps of Engineers, Portland District, Design Memo no. 7, Supplement no. 4, 24 p.

USACE, 1994, Foundation report, Bonneville second powerhouse, Columbia River, Oregon and Washington-Section 3, Geology: U.S. Army Corps of Engineers, Portland District, unpublished report, p. 8-42. 
Van Den Eeckhaut, M., Poesen, J., Verstraeten, G, Vanacker, V., Nyssen, J., Moeyersons, J., van Beek, L.P.H., and Vanderkerckhove, L., 2007, Use of lidar-derived images for mapping old landslides under forest: Earth Surface Processes and Landforms, v. 32, p. 754-769.

Van Den Eeckhaut, M., Muys, B., Van Loy, K., Poesen, J., and Beeckman, H., 2009, Evidence for repeated re-activation of old landslides under forest: Earth Surface Processes and Landsforms, v. 34, p. 352-365.

Van Den Eeckhaut, M., Poesen, Jean, Gullentops, Frans, Vandekerckhove, Liebeth, and Hervás, Javier, 2011, Regional mapping and characterization of old landslides in hilly regions using lidar-based imagery in southern Flanders: Quaternary Research v. 75, p. 721-733.

Van Den Eeckhaut, M., Poesen, J., Verstraeten, G, Vanacker, V., Nyssen, J., Moeyersons, J., van Beek, L.P.H., and Vanderkerckhove, L., 2007, Use of lidar-derived images for mapping old landslides under forest: Earth Surface Processes and Landforms, v. 32, p. 754-769.

Varnes, D.J., 1978, Slope movement types and processes, in Schuster, R.L., and Krizek, R.J., eds., Landslides-Analysis and control: Washington, D.C., Transportation Research Board Special Report 176, p. 11-33.

Wallace, R.E., 1977, Profiles and ages of young fault scarps, north-central Nevada: Geological Society of America Bulletin, v. 88, p. 1267-1281.

Walsh, T.J., Korosec, M.A., Phillips, W.M., Logan, R.L., and Schasse, H.W., 1987, Geologic map of Washington-Southwest quadrant: Washington Division of Geology and Earth Resources Geologic Map GM-34, scale 1:250,000.

Washington Department of Transportation, 2013, Map of Washington mean annual precipitation: accessed May 10, 2013, http://www.wsdot.wa.gov/publications/fulltext/Hydraulics/WaMeanAnnPrecip.pdf.

Waters, A.C., 1973, The Columbia River Gorge-Basalt stratigraphy, ancient lava dams, and landslide dams, in Beaulieu, J.D., Geologic field trips in northern Oregon and southern Washington: Oregon Department of Geology and Mineral Industries, Bulletin 77, p. 133-162.

Weaver, Russ, and Pringle, P.T., 2003, Use of dendrochronology to date and better understand the Bonneville landslide, Columbia River Gorge, Washington [abs.]: Geological Society of America Abstracts with Programs, v. 35, no. 6, p. 80, http://gsa.confex.com/gsa/2003AM/finalprogram/abstract_67682.htm.

Wells, R.E., and McCaffrey, R., 2013, Steady rotation of the Cascade arc: Geology, v. 41, p. 10271030.

Wise, W.S., 1961, The geology of the Wind River area, Washington, and the stability relations of celadonite: John Hopkins University, Maryland, Ph.D. Dissertation, p. 191-195.

Wise, W.S., 1970, Cenozoic volcanism in the Cascade Mountains of southern Washington: Washington State Department of Natural Resources, Bulletin 60, 45 p. 